\title{
Interferon- $\alpha$ and pericardial injury: a case report and literature review
}

\author{
Fayaz A Hakim, ${ }^{1}$ Sujata Singh, ${ }^{3}$ Anil Pandit, ${ }^{1}$ Jorge R Alegria, ${ }^{1}$ John Camoriano, ${ }^{2}$ \\ Melissa L Stanton, ${ }^{4}$ Farouk Mookadam ${ }^{1}$
}

${ }^{1}$ Department of Cardiovascular Diseases, Scottsdale, Arizona, USA

${ }^{2}$ Hematology-Oncology, Scottsdale, Arizona, USA

${ }^{3}$ Internal Medicine, Scottsdale, Arizona, USA

${ }^{4}$ Laboratory Medicine and pathology, Mayo Clinic, Scottsdale, Arizona, USA

\section{Correspondence to}

Dr Farouk Mookadam, Mayo Clinic College of Medicine, 13400 E Shea Blvd, Scottsdale, AZ 85255, USA; mookadam. farouk@mayo.edu

Received 10 January 2014 Revised 19 February 2014 Accepted 14 March 2014

\section{ABSTRACT}

Interferon- $\alpha$ (IFN- $\alpha)$ alone or in combination with other chemotherapeutic agents has been used in the management of many malignant and non-malignant conditions. Pericarditis with or without pericardial effusion has been reported with IFN- $\alpha$ therapy, and available literature is limited to case reports. Pericardial constriction after interferon use has not been described in the published literature to date. We performed a systematic review of literature to address the demographic features, clinical presentation, diagnosis, treatment and outcome of interferon-related pericardial injury.

\section{CASE SUMMARY}

A 43-year-old male with history of polycythaemia rubra vera (PRV) treated with pegylated interferon $\alpha-2 \mathrm{a}$ (Pegasys; Hoffmann-La Roche, USA) $60 \mathrm{mcg}$ subcutaneous weekly for 15 months presented to the emergency room with a 1 -week history of chest pain and difficulty breathing. No cough was present, the pain was worse with deep inspiration and lying down, relieved by leaning forward and shallow breaths. At initial evaluation, pulse was 90 beats per minute and blood pressure $94 / 60 \mathrm{~mm} \mathrm{Hg}$ with an inspiratory drop of systolic pressure of $10 \mathrm{~mm} \mathrm{Hg}$. There was no jugular venous distension at $45^{\circ}$ recumbent position. Cardiac examination was significant for soft first and second heart sounds. Initial laboratory data including complete blood count, serum chemistry, renal function and liver functions were normal. C-reactive protein (CRP) was elevated at $47.2 \mathrm{mg} / \mathrm{L}$ (normal $3-8 \mathrm{mg} / \mathrm{L}$ ). Chest radiograph showed small left pleural effusion and the 12-lead electrocardiogram showed normal sinus rhythm and normal QRS voltage. CT scan of the chest showed small bilateral pleural effusion and a moderate pericardial effusion (figure 1A). Transthoracic echocardiography (TTE) was notable for a large circumferential pericardial effusion with diastolic right ventricular free wall collapse (figure 1B). Doppler inflow velocities across the mitral and tricuspid valve with respirometer were suggestive of interventricular dependence suggestive of pericardial tamponade. Pericardiocentesis was performed, and $350 \mathrm{~mL}$ of straw-coloured pericardial fluid was drained. A pigtail catheter was placed in the pericardial space. Further laboratory work-up including autoimmune and vasculitis serologies were negative. Microbiological testing including viral (human immunodeficiency, Epstein-Barr, cytomegalovirus, coxsackie $\mathrm{B}$, and parvo virus) serology, fungal (coccidioidomycosis, histoplasmosis and blastomycosis) serology, streptococcal and legionella urine antigens and blood cultures were negative. Pericardial fluid analysis showed a total of 100 white cells per cubic millilitre (lymphocytes 80 and segmented 2), proteins $5.8 \mathrm{gm} / \mathrm{L} \quad($ serum $3.4 \mathrm{gm} / \mathrm{L}$ ) and lactate dehydrogenase $246 \mathrm{U} / \mathrm{L}$ (serum $122 \mathrm{U} / \mathrm{L}$ ). Pericardial fluid Gram, acid fast and fungal stains and microbiological cultures were negative. The patient continued to have significant drainage (>150 cc /24 h) $96 \mathrm{~h}$ after the placement of pericardial drain. The patient therefore underwent video assisted thorascopic surgery via a subxiphoid approach with pericardial fluid drainage and pericardial biopsy. A pericardial window with a pericardial drain and a left chest tube were placed to help drain the pericardial and pleural fluids, respectively. Pericardial biopsy revealed dense fibrous tissue with marked mixed cellular infiltration and fibrohistiocytic proliferation suggesting acute and chronic inflammation (figure 2). Pericardial tissue Gram, acid fast, fungal stains and cultures were negative. There was no evidence of malignancy.

Interferon-related pericardial injury was considered, and hence, interferon therapy was discontinued. During the hospital stay the patient remained stable. A single pericardial fluid specimen culture was positive for Propionibacterium acnes, which was deemed a contaminant. Pleural and pericardial drainage declined over next 5 days and the drains were removed. A small left pleural effusion and tiny circumferential pericardial effusion were noted on follow-up chest radiograph and TTE, respectively. Anti-inflammatory therapy with ibuprofen and colchicine was started. At 4 weeks of follow-up, the patient reported intermittent pleuritic chest discomfort and exertional shortness of breath. A triphasic pleural rub was heard on auscultation of the heart. Erythrocyte sedimentation rate (ESR) and C-reactive protein (CRP) were elevated, and an ECG was normal. Two-D echocardiography showed $4 \mathrm{~mm}$-thick pericardium, pericardial adhesions (figure 3A) and a septal bounce. Doppler inflow studies across the mitral valve (figure $3 \mathrm{~B}$ ) and tricuspid valve (figure 3C) with respirometer showed respirophasic changes consistent with the diagnosis of pericardial constriction. The Doppler flow across the hepatic showed diastolic flow reversal. Cardiac magnetic resonance (CMR) with gadolinium showed delayed pericardial enhancement (figure 4). A tapering course of steroids (prednisone $40 \mathrm{mg}$ daily for 2 weeks, then gradually tapered over 3 months together with colchicine daily) was started with symptomatic improvement. Follow-up echocardiogram showed improvement in pericardial thickness and normalisation of the echocardiography findings. 
Figure 1 Computed tomography scan of chest showing pericardial effusion and bilateral pleural effusion (A). Transthoracic echocardiography (subcostal view) showing circumferential pericardial effusion and diastolic collapse of right ventricular free wall (asterix) (B).
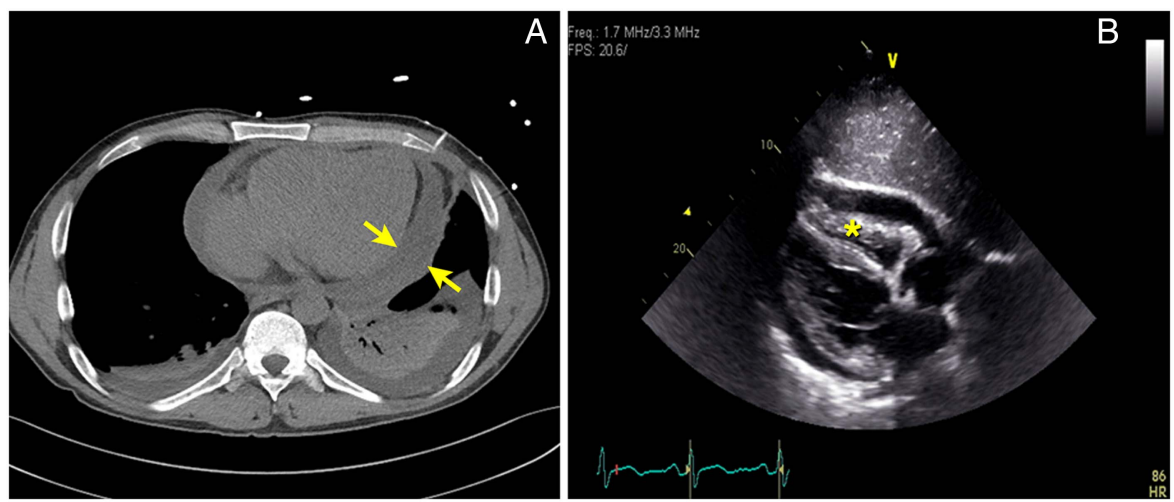

\section{BACKGROUND}

Due to their immunomodulating properties, INF- $\alpha$ has an established role in the management of various malignant and nonmalignant disorders including chronic myelogenous leukaemia, hairy cell leukaemia, renal cell carcinoma, hepatitis $\mathrm{C}$, hepatitis $\mathrm{B}$ and cryoglobulinemia. ${ }^{1}$ Cardiotoxicity is a rare complication of interferon therapy and is more common with INF- $\alpha$ than with INF- $\beta$ or INF- $\gamma$. The cardiotoxicity from interferon treatment may manifest as arrhythmia (48\%), acute coronary syndrome (21\%), and congestive heart failure (12\%). ${ }^{1}{ }^{2}$ Interferon-related pericardial injury in the form of pericarditis, pericardial effusion, or both have been reported to occur, but is less commonly encountered than other cardiac complications. ${ }^{2-9}$ Pericardial effusion associated with INF- $\alpha$ may progress to tamponade necessitating emergency pericardiocentesis. ${ }^{9}$ To the best of our knowledge based on the literature search this is the first case of interferon therapy-related pericardial injury that progressed to pericardial constriction. It is important that physicians, especially those using interferons, be cognisant of this important and disabling complication. Since pericardial injury due to interferon use is rare, and available literature is limited to case reports, we performed a systematic review of literature to address the mechanism of injury, management options, and short-term and long-term outcomes in patients with interferonrelated pericardial injury.

\section{METHODS}

An independent electronic search of PubMed, Medline and Ovid for literature published in English language, from 1 January 1990 to 31 December 2012, was performed by an

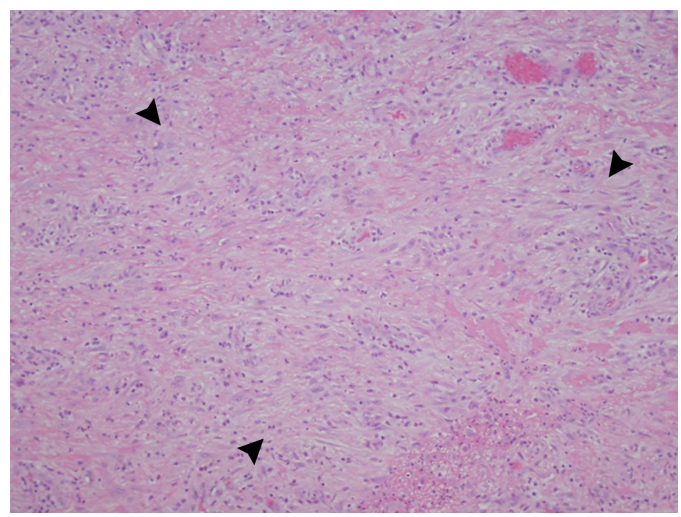

Figure 2 An H \& E-stained section of pericardium shows a fibrohistiocytic proliferation (arrows) in a background of acute and chronic inflammatory cells $(20 x, \mathrm{HE})$. experienced librarian and one of the authors (FH), using 'interferon' 'pericarditis' and 'inflammation' as search terms. Further search using OVID, SCOPUS, CINAHL and Embase as search engines and 'alpha-a-interferon' 'alpha-2a-interferon' 'interferon- $\alpha$ ' 'pegylated' 'pericardial injury' 'interferon gamma' 'interferon beta' as additional search terms was performed for citations possibly missed during initial search. We scanned the bibliographies of the articles retrieved during the searches to identify further reported cases. Care was taken to avoid duplication of the cases included in the study. We reviewed and analysed the demographic profile, clinical features, diagnostic modalities, treatment and outcome of all reported cases with interferon related pericardial injury.

\section{FINDINGS}

The search identified 7 cases of interferon-related pericardial injury reported over the past two decades. These were $2(23 \%)$ males, $4(57 \%)$ females, and gender in one case was not mentioned. The mean age was 42 years (range $24-67$ years). The demographic data, clinical characteristics, management and outcome of the reported case are summarised in table 1 .

Two patients had pericarditis without pericardial effusion. The diagnosis in these cases was made clinically based on prototypical chest pain with respirophasic nature in one and referred left shoulder pain in another. Both patients had a pericardial friction rub on cardiac auscultation. Five patients had a pericardial effusion confirmed on TTE. Exertional shortness of breath was reported by 4, bilateral lower extremity oedema by 3 and chest pain by 2 patients; of whom 1 had ST segment elevation suggestive of acute pericardial injury on ECG. The pericardial effusion was reported to be moderate in 3 patients. One patient had echocardiographic evidence of tamponade requiring pericardiocentesis. ${ }^{9}$ Global myocardial dysfunction, in addition to ECG evidence of pericardial injury, was reported in 1 patient. $^{6}$ Three of 7 patients reported fatigue, and 1 had fever at the time of presentation.

All the patients had received INF- $\alpha$ in doses ranging from $3 \times 10^{6}$ units three times a week to $32 \times 10^{6}$ units daily subcutaneously. The mean time lag from commencement of interferon therapy to the onset of pericardial injury was 314 days (range 5 days to 17 months). Five of 7 patients developed pericarditis while on interferon and 2 developed 3-4 months after the discontinuation of the drug. The indications for INF- $\alpha$ therapy included chronic hepatitis C infection (4/7), malignant melanoma (2/7), and chronic myelogenous leukaemia (1/7). The dose, duration of treatment, and indications of interferon treatment are summarised in table 2. 
Figure 3 Mitral (A) and tricuspid (B) inflow Doppler signals with respirometer showing $>25 \%$ change in mitral and $>40 \%$ change in tricuspid inflow Doppler velocities during respiratory cycle consistent with pericardial constriction.
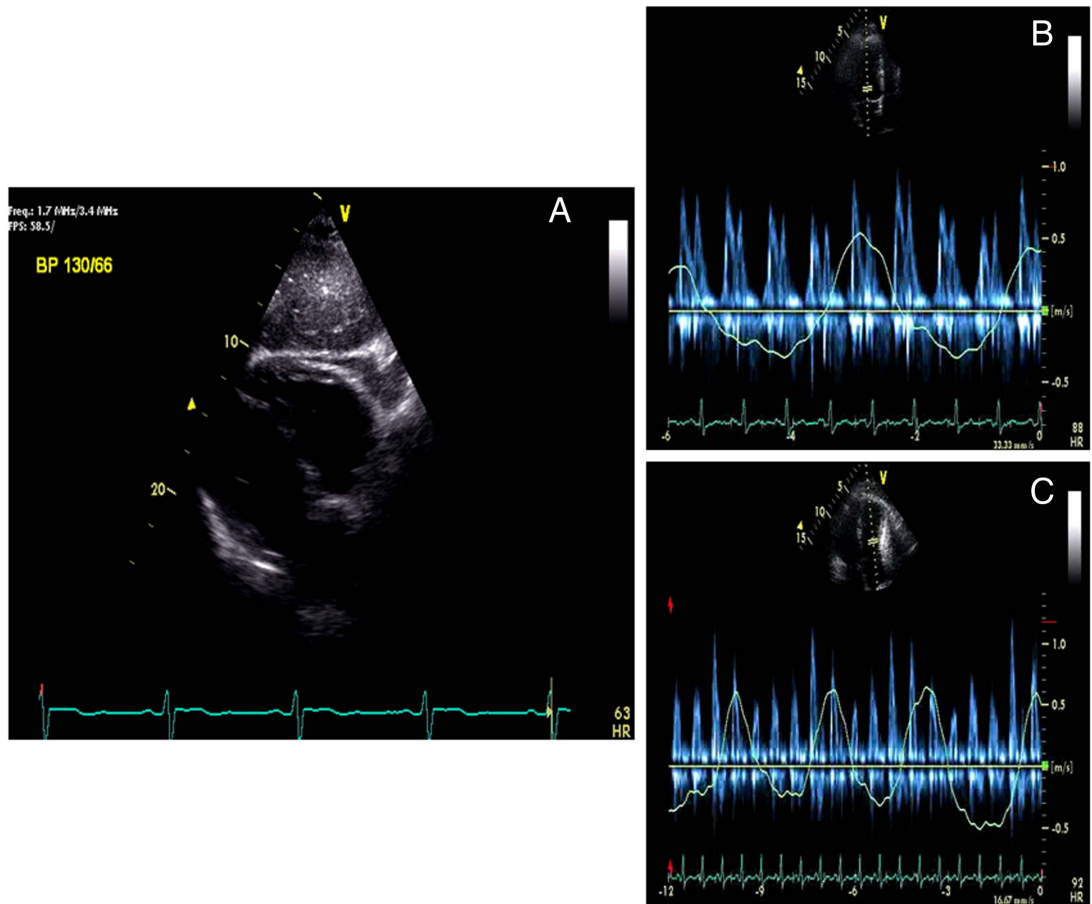

Three of four patients were reported to have elevated inflammatory markers (ESR and CRP). Autoimmune markers were elevated in four patients. Two patients had clinical and serological criteria for the diagnosis of systemic lupus erythematosus (SLE) ${ }^{2}$ and one for limited scleroderma. ${ }^{7}$ Clinical and serological remission followed discontinuation of interferon therapy in both these patients. Pericardial fluid analysis performed in one case was a lymphocyte predominant exudate. Pericardial biopsy was not performed in any of the published reports. Autoimmune serologies and pericardial fluid studies of the reported cases are summarised in table 3.

Discontinuation of interferon therapy together with administration of a tapering course of steroids (4/7) and non-steroidal anti-inflammatory drugs (NSAID) (2/7) cases resulted in complete resolution of pericarditis and or pericardial effusion. Hydroxychloroquine was added to steroids in one and to NSAID in another patient. ${ }^{2}$ The steroids were used in doses of 10-50 mg daily, and tapered over 2-4 weeks. Intravenous immunoglobulin was used in one patient in addition to

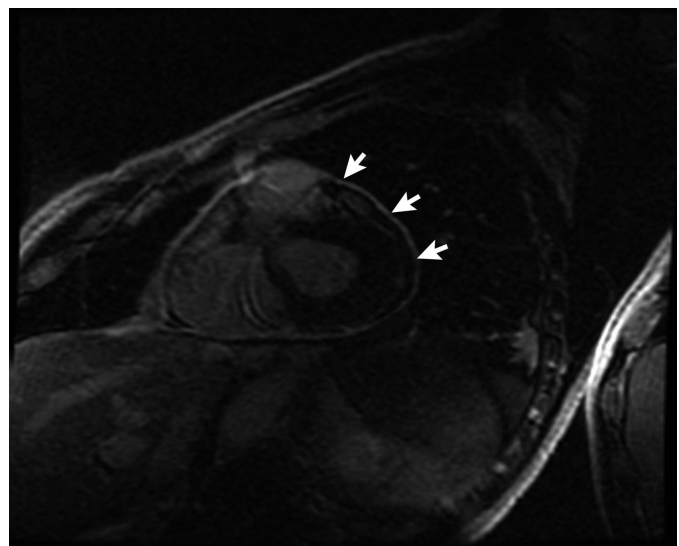

Figure 4 Magnetic resonance imaging with gadolinium showing delayed enhancement of the pericardium (arrows). prednisone and hydroxychloroquine to help with concomitant demyelinating neuropathy. ${ }^{5}$ One patient with tamponade was treated with pericardiocentesis in addition to discontinuation of interferon. Three patients developed recurrent pericardial injury after interferon was restarted. Clinical resolution followed on discontinuation of the offending drug. Furosemide was used in three patients to relieve peripheral oedema.

\section{DISCUSSION}

From the literature review spanning the recent two decades, interferon-related pericardial injury appears to be very rare. Although all the types of interferons are known to cause cardiotoxicity, all reported cases of pericarditis and or pericardial effusion are related to the use of INF- $\alpha$. This is likely because INF- $\alpha$ is the most common interferon used in clinical practice.

The pericardial injury from INF- $\alpha$ use occurs during the treatment of viral infections and malignant disorders. This complication occurs with conventional and pegylated interferons regardless of the dose and the duration of interferon therapy. The pericardial injury may occur soon after the introduction of interferon therapy, or follow days to months after the discontinuation of the drug. Whether pegylation increases the risk of developing pericarditis or other cardiac or non-cardiac complication is not known. However, since pegylated interferon takes a longer time to eliminate from the body, it may take a longer time for resolution of pericardial injury following discontinuation of the pegylated interferons. The same reasons would explain the development of pericardial injury even after the discontinuation of the interferon treatment.

Interferon- $\alpha$ has been shown to cause an upregulation of genes associated with class 1 major histocompatibility complex (MCH-1) molecules, potentiating T-cell and natural killer cell activity, release of proinflammatory cytokines, especially TNF$\alpha$, IL-2, IL-6, IL-1, and generation of immune complexes and autoreactive antibodies. $^{2}{ }^{10-16}$ These factors alone, or in combination, result in an inflammatory state with infiltration of inflammatory cells and immune complexes into the pericardium resulting in pericardial injury. ${ }^{4}$ The induction or upregulation of 
Table 1 Showing demographic characteristics, clinical features, and management of identified patients with Interferon related pericardial injury

\begin{tabular}{|c|c|c|c|c|c|c|c|c|c|c|c|c|c|c|c|}
\hline \multirow[b]{2}{*}{$\mathbf{n}$} & \multirow[b]{2}{*}{ Author year } & \multirow[b]{2}{*}{$\begin{array}{l}\text { Age/ } \\
\text { sex }\end{array}$} & \multirow[b]{2}{*}{$\begin{array}{l}\text { Presenting } \\
\text { complaints }\end{array}$} & \multirow[b]{2}{*}{$\begin{array}{l}\text { Clinical } \\
\text { findings }\end{array}$} & \multirow[b]{2}{*}{ CXR } & \multirow[b]{2}{*}{$\begin{array}{l}\text { Associated } \\
\text { problems }\end{array}$} & \multicolumn{5}{|c|}{ Diagnostic evaluation } & \multicolumn{3}{|l|}{ Treatment } & \multirow[b]{2}{*}{ Outcome } \\
\hline & & & & & & & ECG & TTE & Chest CT scan & DPC & PBx & Conservative & TPC & $\begin{array}{l}\text { Pericardial } \\
\text { window }\end{array}$ & \\
\hline 1 & Fava, 1996 & $\begin{array}{l}28 / \\
\mathrm{NA}\end{array}$ & Chest pain & NA & NA & & NA & Modest PE & NA & NA & NA & INF D/C prednisone & NA & NA & $\begin{array}{l}\text { PE resolved relapse with } \\
\text { reuse }\end{array}$ \\
\hline 2 & $\begin{array}{l}\text { Boonen, } \\
1999\end{array}$ & $24 / F$ & $\begin{array}{l}\text { Left shoulder pain, } \\
\text { fever, fatigue }\end{array}$ & PFR & NA & & NA & NA & NA & NA & NA & Prednisone, chloroquine & NA & NA & $\begin{array}{l}\text { PE resolved relapsed with } \\
\text { reuse } \times 3\end{array}$ \\
\hline 3 & $\begin{array}{l}\text { Gressens, } \\
2004\end{array}$ & $40 / \mathrm{F}$ & LE oedema, SOB, & $\begin{array}{l}\mathrm{B} / \mathrm{L} \mathrm{LE} \\
\text { oedema }\end{array}$ & NA & $\begin{array}{l}\text { Sensory } \\
\text { neuropathy }\end{array}$ & $\begin{array}{l}\text { Non specific } \\
\text { ST changes }\end{array}$ & $\begin{array}{l}\text { PE without } \\
\text { temponade }\end{array}$ & NA & NA & NA & INF D/C aspirin & NA & NA & PE Resolved \\
\hline 4 & $\begin{array}{l}\text { Benjamini, } \\
2007\end{array}$ & $63 / \mathrm{M}$ & Chest pain, SOB & PFR & $\begin{array}{l}\text { CMG B/ } \\
\text { L PLE }\end{array}$ & $\begin{array}{l}\text { Bilateral PLE } \\
\text { CHF }\end{array}$ & NA & $\begin{array}{l}\text { Global systolic } \\
\text { dysfunction }\end{array}$ & NA & NA & NA & Dexamethasone furosemide & NA & NA & $\begin{array}{l}\text { Pericarditis resolved and } \\
\text { CHF improved }\end{array}$ \\
\hline 5 & Nishoi, 2010 & $67 / M$ & SOB, B/L LE oedema & $\begin{array}{l}\mathrm{B} / \mathrm{L} \mathrm{LE} \\
\text { oedema }\end{array}$ & $\begin{array}{l}\text { CMG BL } \\
\text { PLE }\end{array}$ & B/L PLE DPN & $\begin{array}{l}\text { ST elevation } \\
\text { (V1-V6) }\end{array}$ & Moderate PE & PE, PLE & NA & NA & $\begin{array}{l}\text { INF D/C prednisone, } \\
\text { chloroquine IVIG, } \\
\text { furosemide }\end{array}$ & NA & NA & $\begin{array}{l}\text { Pericarditis resolved and } \\
\text { DNP improved }\end{array}$ \\
\hline 6 & $\begin{array}{l}\text { Popescu, } \\
2011\end{array}$ & $38 / \mathrm{F}$ & $\begin{array}{l}\text { Chest pain, } \mathrm{SOB} \text {, } \\
\text { fatigue }\end{array}$ & $\begin{array}{l}\text { Muffled } \\
\text { heart sounds }\end{array}$ & $\mathrm{N}$ & & N & $\begin{array}{l}\text { PE without } \\
\text { tamponade }\end{array}$ & NA & NA & NA & INF D/CI ibuprofen & NA & NA & $\begin{array}{l}\text { PE resolved recurrence } \\
\text { with reuse and resolution } \\
\text { on D/C }\end{array}$ \\
\hline 7 & Rauw, 2012 & $31 / \mathrm{F}$ & $\begin{array}{l}\text { Chest pain, SOB, B/L } \\
\text { LE oedema, fatigue }\end{array}$ & $\begin{array}{l}\text { JVD, B/L LE } \\
\text { oedema }\end{array}$ & NA & & Low voltage & $\begin{array}{l}\text { Moderate PE with } \\
\text { tamponade } \\
\text { physiology }\end{array}$ & Moderate PE & yes & NA & INF D/C & yes & NA & PE Resolved \\
\hline 8 & Hakim, 2013 & $43 / \mathrm{M}$ & Chest pain, SOB & $\mathrm{N}$ & Left PLE & B/L PLE & $\mathrm{N}$ & $\begin{array}{l}\text { Moderate to large PE } \\
\text { with tamponade }\end{array}$ & $\begin{array}{l}\text { Moderate PE } \\
\text { and B/L PLE }\end{array}$ & Yes & Yes & $\begin{array}{l}\text { INF D/C ibuprofen } \\
\text { +colchicine steroids }\end{array}$ & Yes & Yes & $\begin{array}{l}\text { Progressed to pericardial } \\
\text { constriction }\end{array}$ \\
\hline
\end{tabular}

B/L, bilateral; CHF, congestive heart failure; CXR, chest radiograph; D/C, discontinued; DNP, demyelinating neuropathy; DPC, diagnostic pericardicentesis; F, female; INF, interferon; JVD, jugular venous distension; LE, lower extremity; M, male; $n$, case number; N, normal; NA, not available; PBX, pericardial biopsy; PE, pericardial effusion; PFR, pericardial friction rub; PLE, pleural effusion; SOB, shortness of breath; ST, ST segment; TPC, therapeutic pericardiocentesis; TTE, transthoracic echocardiogram. 
Table 2 Showing interferon type, indications and time to diagnosis of pericardial injury

\begin{tabular}{llllllll}
\hline $\mathbf{n}$ & Author/year & $\begin{array}{l}\text { Interferon } \\
\text { type }\end{array}$ & Indication & Dose & $\begin{array}{l}\text { Duration of } \\
\text { treatment }\end{array}$ & $\begin{array}{l}\text { Time to } \\
\text { diagnosis }\end{array}$ & Autoimmune markers \\
\hline 1 & Fava/1996 & IFN- $\alpha$ & CML & $9 \times 10^{6} \mathrm{U}$ daily & $10 \mathrm{M}$ & $3 \mathrm{M} \mathrm{AD}$ & ANA (+) \\
2 & Boonen/1999 & IFN- $\alpha$ & Hepatitis C & $3 \times 10^{6} \mathrm{U} 3 \mathrm{wk}$ & $17 \mathrm{M}$ & $17 \mathrm{M} \mathrm{AS}$ & ANA (+), ds-DNA (+) (SLE) \\
3 & Gressens/2004 & IFN- $\alpha 2 \mathrm{~b}$ & Hepatitis C & $3 \times 10^{6} \mathrm{U}$ wk & $12 \mathrm{M}$ & $4 \mathrm{M} \mathrm{AD}$ & $\mathrm{NA}$ \\
4 & Benjamini/2007 & IFN- $\alpha 2 \mathrm{~b}$ & Malignant melanoma & $18 \times 10^{6} \mathrm{U}$ daily & $30 \mathrm{D}$ & $30 \mathrm{D} \mathrm{AS}$ & $\mathrm{NA}$ \\
5 & Nishoi/2010 & IFN- $\alpha 2 \mathrm{~b}$ & Hepatitis C & $180 \mu \mathrm{g}$ a wk & 14 days & $14 \mathrm{D} \mathrm{AS}$ & ANA (+), ds-DNA (+) \\
6 & Popescu/2011 & Peg IFN- $\alpha 2 \mathrm{~b}$ & Hepatitis C & $180 \mu \mathrm{g}$ a wk & $7 \mathrm{M}$ & $7 \mathrm{M} \mathrm{AS}$ & NA \\
7 & Rauw/ 2012 & IFN- $\alpha 2 \mathrm{~b}$ & Malignant melanoma & $32 \times 10^{6} \mathrm{U}$ daily & $5 \mathrm{D}$ & $5 \mathrm{D} \mathrm{AS}$ & ANA (+) (limited scleroderma) \\
8 & Hakim/2013 & Peg IFN- $\alpha 2 \mathrm{~b}$ & PRV & $60 \mu \mathrm{g}$ a wk & $15 \mathrm{M}$ & $15 \mathrm{M}$ & ANA (-), ds-DNA (-), RF (-) Anti-GBM (-), ANCA (-)
\end{tabular}

$(-)$, negative; (+), positive; 3 wk, three times a week; $\mu \mathrm{g}$, microgram; $A D$, after discontinuation of interferon; ANA, antinuclear antibodies; ANCA, antineutrophil cytoplasmic antibody; anti-GBM, antiglomerular basement ant; AS, after starting inteferon; CML, chronic myelogenous leukaemia; D, days; ds-DNA, double-strand deoxyribonucleotide acid; IFN, interferon;

$\mathrm{M}$, month; $\mathrm{n}$, case number; Peg, pegylated; PRV, polycythaemia rubra vera; RF, rheumatoid factor; SLE, systemic lupus erythematosus; U, units; wk, week.

Table 3 Showing patterns of inflammatory markers, pericardial fluid and pericardial biopsy

\begin{tabular}{|c|c|c|c|c|c|c|c|c|c|}
\hline \multirow[b]{2}{*}{ n A } & \multirow[b]{2}{*}{ Author/year } & \multicolumn{2}{|c|}{ Inflammatory markers } & \multicolumn{5}{|c|}{ Pericardial fluid analysis } & \multirow[b]{2}{*}{ Pericardial biopsy } \\
\hline & & $\begin{array}{l}\text { ESR } \\
\text { (mm 1st hour) }\end{array}$ & $\begin{array}{l}\text { CRP } \\
\text { (mg/dL) }\end{array}$ & $\begin{array}{l}\text { Total } \\
\text { cells }\end{array}$ & Differentials & $\begin{array}{l}\mathrm{PF} / \text { serum } \\
\text { protein ratio }\end{array}$ & $\begin{array}{l}\text { PF/serum } \\
\text { LDH ratio }\end{array}$ & Others & \\
\hline 1 & Fava/1996 & 35 & NA & NA & & & & & NA \\
\hline 2 & Boonen/1999 & $\mathrm{N}$ & NA & NA & & & & & NA \\
\hline 3 & $\begin{array}{l}\text { Gressens/ } \\
2004\end{array}$ & NA & $1.2(\mathrm{H})$ & NA & & & & & NA \\
\hline 4 & $\begin{array}{l}\text { Benjamini/ } \\
2007\end{array}$ & 40 & NA & NA & & & & & NA \\
\hline 5 & Nishoi/2010 & NA & $0.1(\mathrm{~N})$ & NA & & & & & NA \\
\hline 6 & $\begin{array}{l}\text { Popescul } \\
2011\end{array}$ & NA & $\begin{array}{l}17 \mathrm{mg} / \mathrm{L} \\
(\mathrm{H})\end{array}$ & NA & & & & & NA \\
\hline 7 & Rauw/2012 & NA & NA & NA & $\begin{array}{l}\text { Lymphocyte } \\
\left(27 \times 10^{6} / L\right)\end{array}$ & NA & NA & $\begin{array}{l}\text { Microbiology (-) Malignant cells } \\
(- \text { Mesothelial cells (+) }\end{array}$ & NA \\
\hline 8 & Hakim/2013 & NA & $\begin{array}{l}42 \mathrm{mg} / \mathrm{L} \\
(\mathrm{H})\end{array}$ & 100 & Lymphocytes (80) & $>0.5$ & $>0.6$ & Microbiology (-) Malignant cells (-) & $\begin{array}{l}\text { Acute \& chronic } \\
\text { inflammation }\end{array}$ \\
\hline
\end{tabular}

pre-existing autoreactive antibodies in genetically susceptible individuals may lead to subclinical or clinically manifest autoimmune disorder with secondary pericardial involvement as reported in four cases. ${ }^{3} 479$ A direct effect of the interferons on pericardial tissue could be another potential mechanism of pericarditis.

Pericardial effusion with or without pericarditis occurs more frequently than pericarditis alone. The classical ECG changes of pericardial injury due to interferon pericarditis are uncommon. Progression to pericardial tamponade requiring pericardiocentesis may occur. Discontinuation of interferon therapy together with tapering course of corticosteroids or NSAID alone or in combination with chloroquine results in resolution of pericarditis and or pericardial effusion. Patients who present with clinical and or echocardiographic evidence of tamponade require pericardiocentesis. Intrapericardial triamcinolone acetate has been shown to be effective in the treatment of autoreactive pericarditis with fewer systemic side effects. ${ }^{17}$ This option may hold true with interferon-related pericardial injury as well. The case presented here is unique where progression to pericardial constriction was noted despite INF- $\alpha$ being discontinued and initial response to tapering course of steroids. Surgical pericardiectomy may be considered in patients with features of constriction even in absence of evidence of inflammation. Lastly, other complications of interferons may occur in conjunction with pericardial inflammation especially cardiomyopathy and peripheral neuropathy that may need additional medical interventions.

\section{CONCLUSIONS}

Interferon- $\alpha$-related pericarditis, and/or pericardial effusion, is rare. Cardiac tamponade and progression to pericardial constriction can occur. Physicians involved in the care of patients using interferon should have a high degree of suspicion for pericardial injury among patients who present with chest pain and/or shortness of breath even after the drug has been discontinued. Discontinuation of interferon together with a course of steroids or NSAIDs are effective treatments.

Contributors FM and FAH: conception and design literature review. FAH, SS, AP, MLS: acquisition of data. FAH, FM: analysis and interpretation of data. FAH, FM, AP, SS: drafting of the manuscript. Critical revision of the manuscript for important intellectual content: Mookadam (research methodology, concept, idea, design, data, general oversight), Camoriano (heme-oncology expert), Alegria (clinical expert), Hakim (writing, editing, literature review independently, data collation).

Competing interests None.

Patient consent Obtained.

Provenance and peer review Not commissioned; externally peer reviewed. 


\section{REFERENCES}

1 Sleijfer S, Bannink M, Van Gool AR, et al. Side effects of interferon-alfa therapy. Pharm World Sci 2005;27:423-31.

2 Sonnenblick M, Rosin A. Cardiotoxicity of interferon. A review of 44 cases. Chest 1991;99:557-61.

3 Fava S, Luoni M, Stioui S. Pericarditis during interferon- $\alpha$ therapy in chronic myelogenous leukemia- Letter to Editor. Haematologica 1996;81:484.

4 Boonen A, Stockbrügger RW, Van der Linden S. Pericarditis after interferon- alfa for chronic hepatitis C. Clin Rheumatol 1999;18:177-9.

5 Gressens B, Gohy P. Pericarditis due to interferon- $\alpha$ therapy during treatment for chronic hepatitis C. Acta Gastrenterol Belg 2004;67:301-2.

6 Benjamini 0, Kimhi O, Lishner M. Severe Pleuropericarditis and Cardiomyopathy Induced by High Dose Interferon alpha-2b. IMAJ 2007;9:486-7.

7 Nishio K, Konndo T, Okada S, et al. Pericarditis and chronic inflammatory demyelinating polyneuropathy during therapy with pegylated interferon alfa-2a for chronic hepatitis C. World J Hepatol 2010;2:358-61.

8 Popescu C, Arama V, Gliga S. Acute pericarditis due to pegylated interferon alpha therapy for chronic HCV hepatitis-Case report. BMC Gastroenterology 2011;11:30.

9 Rauw J, Ahmed S, Petrella T. Pericardial effusion and tamponade following interferon alpha treatment for locally advanced melanoma. Med Oncol 2012;29:1304-7.
10 Outzen MA, Crowley S. Interferons Play a Central Role in the Natural Defense and Therapeutic Management of Hepatitis C: A Review. Internet J Gastroenterol 2007;5.

11 Takahashi $\mathrm{H}$, Nishimura $\mathrm{M}$, Sakamoto $\mathrm{M}$, et al. Effects of interleukin-1 beta on blood pressure, sympathetic nerve activity, and pituitary endocrine functions in anesthetized rats. Am J Hypertens 1992;5:224-9.

12 Ristić $A D$, Pankuweit $S$, Maksimović $R$, et al. Pericardial cytokines in neoplastic, autoreactive, and viral pericarditis. Heart Fail Rev 2013;18: 345-53.

13 Maisch B, Seferović PM, Ristic AD, et al. Guidelines on the Diagnosis and Management of Pericardial Diseases. The Task Force on the Diagnosis and Management of Pericardial Diseases of the European Society of Cardiology. Eur Heart J 2004;25:587-610.

14 Pankuweit $\mathrm{S}$, Wädlich $\mathrm{A}$, Meyer $\mathrm{E}$, et al. Cytokine activation in pericardial fluids in different forms of pericarditis. Herz 2000;8:748-54.

15 Karatolios K, Moosdorf R, Maisch B, et al. Cytokines in Pericardial Effusion of Patients with Inflammatory Pericardial Disease. Mediators Inflamm 2012;2012:1-7

16 Okanoue T, Sakamoto $S$, Itoh $Y$, et al. Side effects of high dose interferon therapy for chronic hepatitis C. J Hepatol 1996;25:283-91.

17 Frasiolas JA, Cahoon WD. Intrapericardial triamcinolone administration for autoreactive pericarditis. Ann Pharmacother 2010;44:1641-6. 